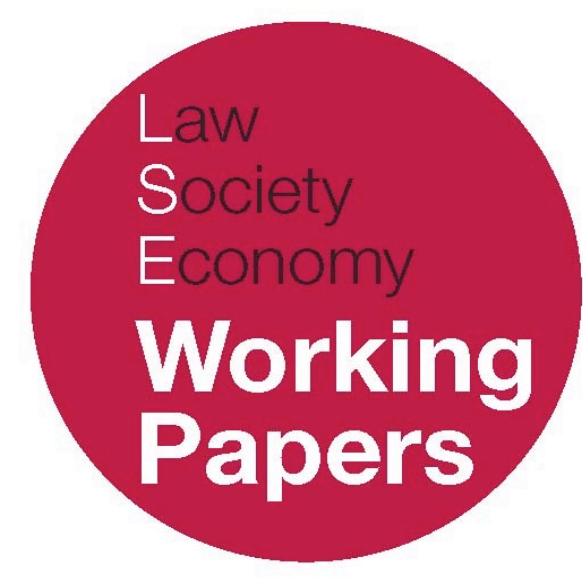

\title{
Dummy Asset Tracing
}

\section{Tatiana Cutts}

LSE Law, Society and Economy Working Papers 4/2018

London School of Economics and Political Science

Law Department

This paper can be downloaded without charge from LSE Law, Society and Economy Working Papers at: www.lse.ac.uk/collections/law/wps/wps.htm and the Social Sciences Research Network electronic library at: https://ssrn.com/abstract=3137285

(C) Tatiana Cutts. Users may download and/or print one copy to facilitate their private study or for non-commercial research. Users may not engage in further distribution of this material or use it for any profit-making activities or any other form of commercial gain. 


\title{
Dummy Asset Tracing
}

\author{
Tatiana Cutts*
}

\begin{abstract}
Tracing is widely understood to be the process of demonstrating that two rights are connected through an exchange, such that a claim to the right given up can be transmitted to the right acquired. This has been termed "exchange-product tracing", and - though its core case is the unauthorised substitution of a trust right - it is also thought that a bank transfer exemplifies a rights-exchange. I argue here that this is a mistake: a bank transfer does not involve a substitution of the kind envisaged by exchange product tracing. Rather, the process that we have called "tracing money" through a bank transfer involves two steps: (i) converting bank money, by artifice, into an asset independent of the underlying account; (ii) following that asset from one location to another. Together, I call these steps "dummy asset tracing".

In this article, I show that the twin steps of dummy asset tracing have led us to increase the ambit of third party liability at law and in equity: by simulating cash transfers, innocent bank payees have been made liable to claimants with whom they did not transact, and of whom they were wholly unaware. I argue that the normative foundations for dummy asset tracing are weak, and that there is authority and appetite for an approach that focuses more closely upon the defendant's proximity to the relevant injustice: if a defendant is liable for sums paid to her by someone other than the claimant, it is either because she actuated or participated in a breach of duty owed to the claimant, or because she is the counterparty to a defective transaction effected by the claimant's agent.
\end{abstract}

${ }^{*}$ Assistant Professor in Law, London School of Economics \& Political Science. 


\section{I.INTRODUCTION}

Since at least 2001, it has been widely accepted that tracing is the process of demonstrating that two rights are connected through an exchange, such that a claim to the right given up can be transmitted to the right acquired. This has been termed "exchange-product tracing", and its core case is the unauthorised substitution of a trust right: if $\mathrm{T}$, who holds $\mathrm{R}$ on trust for $\mathrm{B}$, swaps it for $\mathrm{R} 2$ in excess of her authority, $\mathrm{B}$ can claim R2 as the traceable proceeds of $\mathrm{R}$. It is also thought that a bank transfer exemplifies such a substitution: if $\mathrm{T}$, who holds account $\mathrm{R}$ on trust for $\mathrm{B}$, diverts trust funds from $\mathrm{R}$ to the account of a third party, $\mathrm{X}, \mathrm{X}$ receives and can be made accountable for the traceable proceeds of B's prior claim. This is important: almost all putative instances of tracing involve one or more such transfers.

I argue here that a bank transfer does not involve a substitution of the kind envisaged by exchange product tracing. Rather, the process that we have called "tracing money" through a bank transfer involves two steps: (i) converting bank money, by artifice, into an asset independent of the underlying account; (ii) following that asset from one location to another. Together, I call these steps "dummy asset tracing": exchange product tracing is the process of linking two rights through an exchange by a single person; dummy asset tracing is the process of pursuing a notional asset (thing or right) from one person to another.

In the first part of this article, I describe the orthodox account of exchangeproduct tracing, and argue that we should treat bank transfers as a case apart from unauthorised substitution. In the second, I explain how we have substantiated the connection between the claimant from whom bank money has been misdirected, and the third party to whom it has been paid. I call this "dummy asset tracing", and I show that it manifests differently at law and in equity: in equity, the claimant follows a notional right into the hands of the defendant; at law, the claimant follows a notional physical cash asset.

In the third part of this article, I explain how dummy asset tracing has influenced the development of common law claims in unjust enrichment, and equitable claims against third parties in knowing receipt and for breach of trust. I show that, by pinning liability upon the defendant's putative receipt of an asset to which the claimant had a prior claim (at law or in equity), we have come to replicate the conditions for and consequences of cash transfers in bank payments cases, thereby increasing the ambit of third party liability. By means of dummy asset tracing, an innocent payee may be held liable to a claimant with whom she did not transact, and of whom she was wholly unaware.

In the final part of this article, I argue that the normative foundations for dummy asset tracing are weak, and that there is authority and appetite for an approach that focuses more closely upon the defendant's proximity to the relevant injustice. I argue that, if a defendant is liable for sums paid to her by someone other than the claimant, it is either because she actuated or participated in a breach of duty owed to the claimant, or because she is the counterparty to a defective transaction 
effected by the claimant's agent. In this way, we are able to limit the range of circumstances in which a third party can be held liable for bank money misappropriated.

\section{II.EXCHANGE PRODUCT TRACING AND BANK TRANSFERS}

\section{EXCHANGE PRODUCT TRACING}

The following Example 1 is an iteration of tracing's central case:

Example 1: T, trustee, holds title to a $£ 10$ note on trust for B. T buys with it a bottle of wine, without B's authority.

Although opinions differ as to the logic of any claim that results from such facts, there are two clear facets to the orthodox tracing thesis: (i) tracing is the process of identifying title to the bottle of wine as the exchange product of title to the note (the evidential function); ${ }^{1}$ and (ii) this process of identification plays a role (though perhaps it does not complete the justificatory story) in permitting the claimant to transfer her claim from title to the note to title to the bottle of wine (the relational function). ${ }^{2}$ As Smith puts it:

The fundamental idea underlying tracing is that sometimes, for certain legal purposes, one asset stands in the place of another. A claim which could have been made in relation to the original asset is allowed in relation to the new asset... Tracing is the process which can allow the transmission of that claim to the new asset. ${ }^{3}$

This has been termed "exchange product tracing". ${ }^{4}$

Smith argues that the way in which the claimant (B) establishes a connection between the trust right $(\mathrm{R})$ and its product (R2) is by identifying some feature of R that continues to exist throughout the exchange, which feature he labels "value":

\footnotetext{
1 'Foskett v McKeown [2001] 1 AC 102, 127 (Lord Millett): 'Tracing is the process of identifying a new asset as the substitute for the old', cited in Ultraframe (UK) Ltd v Fielding [2005] EWHC 1638, 1461 by Lewison J for the conclusion that tracing is a 'process not a remedy'. In Armstrong $v$ Winnington [2012] EWHC 10 (Ch) Stephen Morris QC called it 'a means, or process, of identifying an asset as being a substitute for an asset originally held by the claimant', at [65].

2 It brings about 'the transmission of a claimant's property rights from one asset to its traceable proceeds' Foskett v McKeown (Lord Millett) 127. See also NABB Brothers Limited v Lloyds Bank. International (Guernsey) Limited [2005] EWHC 405 (Ch) [75] (Lawrence Collins J) and Armstrong v Winnington [81] (Stephen Morris QC).

${ }^{3}$ L. Smith, The Law of Tracing (OUP 1997).

${ }^{4} \mathrm{C}$ Rotherham, 'Property and Justice' in M Kramer (ed), Rights, Wrongs and Responsibilities (Palgrave Macmillan) 174, fn 133; B. Fitzgerald, 'Tracing at Law, the Exchange Product Theory and Ignorance as an Unjust Factor in the Law of Unjust Enrichment' (1994) 13 University of Tasmania Law Review 117.
} 
The defendant acquired the value inherent in the new asset with the value inherent in the old asset. That is why we say that we trace value: it is the only constant that exists before, through and after the substitution through which we trace. It exists in a different form after the substitution, and that is what can justify a claim to the new asset. ${ }^{5}$

I have argued elsewhere that this is misleading - that it has, in fact, misled courts seeking to apply principles of tracing. "Value", in tracing, is the susceptibility of R to exchange: when $\mathrm{T}$ acquires $\mathrm{R} 2$ with $\mathrm{R}$, transferring $\mathrm{R}$ to $\mathrm{X}$ and taking $\mathrm{R} 2$ for herself, she exploits the exchange potential inherent in $\mathrm{R}$. Exchange potential cannot move from $\mathrm{R}$ to $\mathrm{R} 2$ : the result of the translation is that $X$ is now in a position to exploit the exchange potential of $\mathrm{R}$.

Yet, there is one element of continuity present in any rights-exchange, which is essential to its characterisation as such. As Smith puts it: "the only connection between the old and the new asset is the exchange; that is, the substitution of one for the other by some person". ${ }^{7}$ That feature of Example 1 which allows us to show that title to the bottle of wine is the substitute of title to the $f_{10}$ note, and so to make good the assertion of tracing's first facet, is T's role as the agent of exchange: T gives up title to the note $(\mathrm{R})$ and acquires title to the wine (R2) in its place.

We rarely dwell on T's role in exchange product tracing. Instead, we emphasise that R2 "is the potential subject matter of a claim" because it is the substitute for R, "which was itself the subject matter of a claim". ${ }^{8}$ But what makes Example 1 a compelling case for rights-transmission (the relational function) is not only B's initial claim to $\mathrm{R}$; it is also the fact that $T$ was situated at the opposite end of that claim. Prior to exchange, $\mathrm{T}$ was liable to $\mathrm{B}$ for title to the note (R). If $\mathrm{T}$ exploits the exchange potential of $R$, acquiring title to the wine (R2) in exchange, she puts it outside her power to deliver R to B. Whichever conceptual tools we use to clothe this more precisely, ${ }^{9}$ the peculiar role of exchange product tracing is to allow $\mathrm{B}$ to claim R2, thereby treating T's liability for R2 as the best proxy for T's liability for R. It is in this sense that B's claim to $\mathrm{R}$ is "represented by" a claim to R2.10 Thus, exchange product tracing demands that a single actor $-\mathrm{T}$ - give up and receive the relevant rights; thus it permits $\mathrm{B}$, without more, to transpose her claim.

\footnotetext{
${ }^{5}$ Smith 119. Birks, too, wrote that 'a person who sets out on a tracing exercise aims to show that the value of an asset was used to obtain another' P. Birks, 'Taking Seriously the Differences Between Tracing and Claiming' (1997) 11 TLI 2, 4.

${ }^{6}$ T. Cutts, 'Tracing, Value and Transactions' (2016) 79 MLR 381; See now C. Mitchell, P. Mitchell and S. Watterson (eds), Goff \& Jones: The Law of Unjust Enrichment (9th edn, Sweet \& Maxwell) Chapter 7.

${ }^{7}$ Smith 134 .

${ }^{8}$ Ibid 6.

${ }^{9}$ This does not commit us to a particular view of the reason for liability. We can clothe this in various ways: the best way to remedy breach of trust; T's liability for R2 follows from T's primary fiduciary liability to account for rights acquired; $\mathrm{T}$ would be unjust enriched by $\mathrm{R} 2$ if $\mathrm{B}$ were not allocated a claim. 10 Shalson v Russo [2003] EWHC 1637 (Ch); [2005] Ch 281.
} 


\section{EXCHANGE PRODUCT TRACING AND BANK TRANSFERS}

Although many texts treat Example $\mathbf{1}$ as tracing's central case, the vast majority of tracing cases involve a set of facts more akin to the following Example 2:

Example 2: T, a trustee, holds an account on trust for B. T transfers $£ 10$ from the trust account to that of a third party, X, without B's authority.

In these cases, the principles of tracing are used in the same way, to demonstrate that X's account (R2) is the traceable product of the trust account (R). ${ }^{11}$ The present editors of Goff \& Jones: The Law of Unjust Enrichment put it thus: "it is well accepted that it is possible to trace through inter-account bank transfers, so as to identify the credit to the transferee's account as the product of the debit to the paying customer's account, whether the transfer is "in-house" or "inter-bank".12 Where one or more accounts are interposed between $\mathrm{R}$ and R2, B must show that there was a "direct chain of substitutions whereby the claimant's property was exchanged for another asset". 13

There are, in fact, various problems with identifying a rights-exchange of the requisite kind in Example 2. ${ }^{14}$ The first is that there have been various arguments to the effect that a bank payment does not involve a loss and acquisition of rights at all. In Evans v European Bank, ${ }^{15}$ Spigelman CJ considered that a bank transfer from one account to another could not constitute a rights-exchange, because the transferor account - the right putatively substituted - "always existed and still exists": 16 an account holder has a single claim to whatever is the present total of her account, which claim remains in her hands following the alleged substitution.

I do not think it possible to determine whether, as a matter of principle, Spigelman CJ's conclusion is superior to an alternative that would recognise a rightsexchange from the facts of a bank transfer. ${ }^{17}$ Whether a bank transfer does indeed involve a loss and acquisition of rights simply depends upon the level of abstraction at which it is viewed. If $\mathrm{T}$ holds $f^{20}$ in her account prior to the transfer, we can either say that the effect of the transfer upon her account is: (i) to decrease the value of her (pre-existing) right to $£ 10$, or; (ii) to replace her right with a new one, worth $f_{10}$. Either is plausible.

\footnotetext{
11 See e.g. Banque Belge pour l'Etranger v Hambrouck [1921] 1 KB 321; Trustee of FC Jones v Jones [1997] Ch 159; Independent Trustee Services v GP Noble Trustees [2012] EWCA Civ 195; [2013] Ch 91; BCCI v Akindele [2001] Ch 437; [2000] 3 WLR 1423; Relfo v Varsani [2014] EWCA Civ 360.

12 Mitchell, Mitchell and Watterson [7-32].

13 Relfo $v$ Varsani [35] (Ardern LJ).

14 Mitchell, Mitchell and Watterson [7-33]: "there remain difficulties in characterising the chain of intervening transactions as a series of "exchanges of assets".

15 Robb Evans of Robb Evans \& Associates v European Bank Limited [2004] NSWCA 82.

16 Ibid. This passage was cited in Hillig v Darkinjung [2006] NSWSC 1217 [20]

${ }^{17}$ E.g. B McFarlane, 'Unjust Enrichment, Property Rights, and Indirect Recipients' ' [2009] RLR 37; D. Fox, Property Rights in Money (OUP 2008).
} 
Yet, even if we accept the second reading - accept, for present purposes, that a bank transfer involves a loss and acquisition of rights - obstacles remain for the use of exchange product tracing to connect parties to a bank transfer. In particular, the alleged product of the rights substitution in any bank transfer is the credit to the transferee's account; it is on this basis that we connect claimant (B) and defendant (X). Yet, we saw above that exchange product tracing demands a substitution effected by a single actor: the trustee, who was accountable for $\mathrm{R}$, is made accountable for the product of $\mathrm{R}$ in her hands.

We can locate precisely such a substitution on the facts of Example 2, but it will not help us to substantiate a connection between $\mathrm{B}$ and $X$. Suppose that $\mathrm{T}$ in Example 2 held $£ 20$ in the trust account prior to transfer, and that $X$ held $£, 10$ in his account prior to transfer. The effect of the transfer then is as follows: $\mathrm{T}$ gives up one right to $£ 20$, and acquires another to $£ 10$; $X$ gives up one right to $£ 10$ and acquires another to $£ 20$. Thus, the facts of Example 2 reveal not one but two substitutions. ${ }^{18}$ We still have no way of traversing the gap between B, from whose trust account $f_{10} 10$ was misdirected, and $\mathrm{X}$, into whose account it was paid.

Thus, if exchange product tracing is to encompass simple bank transfers, we need an explanation for switching our attention at the evidential stage from the immediate product of T's exchange in T's hands (T's claim to $f 10$ ) to what $X$ got in return for T's exchange (X's claim to $£ 20$ ). ${ }^{19}$ And, at the relational stage, any such explanation must account for the difference between: (i) transmitting a claim to the product of a right for which the present right-holder was accountable to $\mathrm{B}$; and (ii) transmitting a claim to the product of a right for which someone other than the present right-holder was accountable to $\mathrm{B}$.

Smith recognises this explanatory gap, and seeks to fill it by varying the facts of an example akin to Example 1:

Example 1.2: $\mathrm{T}$, trustee, holds title to a $f_{10} 10$ note on trust for $\mathrm{B}$. $\mathrm{T}$ buys with it a bottle of wine, without B's authority. T gives the bottle of wine to $\mathrm{X}$.

According to Smith, if - having received a right to which B has a prior claim $\mathrm{X}$ is liable in Example 2, $\mathrm{X}$ ought also to be liable in a case like the following Example 1.3, in which $T$ simply omits the intermediate step:

\footnotetext{
18 This is reflected in the awkwardness of Ardern LJ's remarks that what matters is that there has been an exchange of the value of the claimant's property into the next product for which it is substituted and so on down the chain of substitutions Relfo v Varsani [60]. See further Cutts, 'Modern Money Had and Received', Forthcoming OJLS.

${ }^{19}$ If it is on account of T's intention to vest the product in X (as I have argued elsewhere, and which explanation the editors of Goff and Jones adopt (Mitchell, Mitchell and Watterson [7-33]), we still need to explain why this intention should permit B's claim to have any impact on X.
} 
Example 1.3: $T$, trustee, holds title to a $£_{10}$ note on trust for $\mathrm{B}$. $\mathrm{T}$ buys with it a bottle of wine, without B's authority, directing the vendor to give the bottle of wine to $\mathrm{X}$.

And this, Smith argues, is precisely how we should think of Example 2, in which $\mathrm{X}$ acquires the right for which $\mathrm{T}$ paid: "The only thing that differentiates this kind of substitution is that $[\mathrm{T}]$ did not himself acquire possession of his purchase". ${ }^{20}$ Smith calls this "tracing in transit". ${ }^{21}$

This property analogy proceeds in three steps. First, it draws upon the logic of the central case: $\mathrm{T}$ is liable for the substitute because $\mathrm{T}$ was liable for the original. Second, it adds a new reason why $\mathrm{X}$ would be liable, given a straightforward variation of the facts: if $\mathrm{X}$ received a right to which $\mathrm{B}$ had a prior claim, $\mathrm{X}$ would have been accountable for that right (absent any defence). Thus (and this is the final step), X should be liable where $\mathrm{T}$ omits the intermediate property transfer, and causes $\mathrm{X}$ to be in immediate receipt of the right.

However compelling Smith's argument may be for Example 1.3, his logic has no force on the facts of Example 2. A bank transfer does not involve the transfer of any right, so that the Example 1.2 counterfactual is impossible. Thus, the second step - the argument that short-circuiting Example 1.2 by omitting a transfer of possession should not alter our conclusion as to X's liability - is a straightforward non sequitur. If there is a reason why Example 2 and Example 1.3 are normatively akin, we have not yet found it.

Yet, I think that Smith's reasoning does provide an important insight into the method by which we have come to incorporate bank transfer cases en masse into our law of tracing. In what follows I seek to demonstrate that the process that we have called "tracing money" through a bank account does not involve exchange product tracing. Instead, it involves two steps: (i) converting bank money, by artifice, into an asset that is segregable from the account itself; (ii) following and locating that asset. Together, I call these steps "dummy asset tracing".

\section{III.DUMMY ASSET TRACING}

\section{DUMMY ASSET TRACING IN EQUITY}

Let us return to Example 2:

Example 2: T, a trustee, holds an account on trust for $\mathrm{B}$. $\mathrm{T}$ transfers $£ 10$ from the trust account to that of a third party, X, without B's authority.

\footnotetext{
20 Smith 248.

${ }^{21}$ Ibid. The editors of Goff and Jones have called this explanation "elegant": Mitchell, Mitchell and Watterson [7-33].
} 
We saw above that exchange product tracing cannot readily encompass the connection between the right that $\mathrm{X}$ acquires and that which $\mathrm{T}$ gives up. In what follows, I show that this connection has been forged by interposing a notional money asset, which $\mathrm{B}$ follows throughout the steps of transfer from $\mathrm{T}$ to $\mathrm{X}$, and which grounds B's claim to X's right. I call this "dummy asset tracing".

\section{Dummy asset tracing in Equity}

In Independent Trustee Services v GP Noble Trustees, 22 some $f, 52 \mathrm{~m}$ was misappropriated from various occupational pension schemes by their corporate trustees, GP Noble Trustees Ltd and BDC Trustees Ltd. Mr Anthony Morris received $f 4.89 \mathrm{~m}$ of those funds, of which he paid $f_{1} 1.48 \mathrm{~m}$ to his former wife, Mrs Morris, to satisfy his liability under a consent order. The trustee of the pension schemes, Independent Trustee Services Ltd ("ITS"), commenced proceedings to recover the trust assets. It was accepted that Mrs Morris could have raised the defence of bona fide purchase at the time of receipt; she had given value in the form of agreeing not to pursue any further claims for ancillary relief. However, she later succeeded in having the consent order set aside, on the basis that Mr Morris' disclosure in the ancillary relief proceedings had been deliberately and materially deficient, and obtained a new order for financial provision. By then, she had notice of the trust provenance of the monies. ITS sought to recover the $f 1.48 \mathrm{~m}$ on the basis that setting aside the consent order negated the effect of the defence, thereby reviving the trust. The Court of Appeal agreed: though Mrs Morris had clearly obtained "legal title to the money" paid to her; the beneficiaries nevertheless could "trace the $£ 1.481 \mathrm{~m}$ into the hands of Mrs Morris on the basis of a subsisting beneficial interest". ${ }^{23}$

In Credit Agricole Corporation and Investment Bank v Papadimitriou, ${ }^{24}$ the court considered an action for the recovery of some US $\$ 10.3$ million, constituting the proceeds of sale of a collection of art deco furniture which had been deposited in a bank in Gibraltar. It was common ground that the defendant bank still had, and that the claimant could trace, the proceeds of sale; the only question was whether the bank could show that it was a bona fide purchaser. Delivering judgment for the Privy Council, Lord Clarke held that it was not: the bank ought to have made inquiries that would have revealed the claimant's pre-existing proprietary right to the funds received; thus, the claimant could recover the money on the basis of that right. Lord Sumption added that it was important to address the question of knowledge from the starting point that "We are in the realm of property rights". 25

Viewed through the lens of exchange product tracing, the courts' treatment of these claims looks odd. If it is the product of (but different from) the right

\footnotetext{
22 Independent Trustee Services v GP Noble Trustees.

${ }^{23}$ Ibid [67].

${ }^{24}$ Credit Agricole Corp and Investment Bank v Papadimitriou [2015] UKPC 13.

25 Ibid [4282].
} 
substituted, the defendant's right cannot be the object of a "subsisting beneficial interest". ${ }^{26}$ Yet, we have already seen that bank transfers do not readily map on to the conceptual framework of exchange product tracing, and it does not seem that this is what the courts in ITS and Papadimitriou had in mind: neither mentioned an "exchange" or "substitution" of rights; each simply identified the object of the tracing exercise, and of the beneficiaries' "continuing beneficial interest" as "the money in [the defendant's] possession". ${ }^{27}$ We are encouraged to assume - indeed, it was common ground in both cases - that the money paid and received remained, for all relevant purposes, the same money throughout.

It is trite that a bank transfer from $\mathrm{T}$ to $\mathrm{X}$ transfers no thing or right from $\mathrm{T}$ to $\mathrm{X}$ - nothing, indeed, but a "stream of electrons", 28 through which T's account is debited and X's credited. ${ }^{29}$ The object of the tracing exercise in these cases - "the money paid" by T to X - is not a thing or right actually transferred, but a notional money asset. In order to support B's claim to bank money misdirected from the trust fund to the account of $\mathrm{X}$, a third party, the court permits B to convert the sum paid and received into a chose in action that exists as an asset independent of the underlying accounts. I have called this process "dummy asset tracing". And understood as the product of a notional asset transfer, the claim from persistence is logically consistent with the fact of a bank payment from $\mathrm{T}$ to $\mathrm{X}$ : if $\mathrm{X}$ receives a notional asset to which $\mathrm{B}$ has some pre-existing claim, we need offer no explanation for X's liability beyond the mere fact of receipt (absent any defence)..$^{30}$

\section{Mixed funds}

This ability of equity, to treat money paid and received as an asset independent of the underlying account, underpins its approach to more complex cases, involving so-called "mixed funds". A "mixed fund" is created where the value of the account into which the claimant seeks to trace is attributable to multiple sources. Take the following Example 3:

Example 3: T, trustee, holds a trust account on trust for B, in which stands $£ 20$. T transfers $£ 10$ from that account into T’s current account, in which stands $f, 10$.

Without dummy asset tracing, the fact of a bank transfer simpliciter (with or without the addition of subsequent payments in or drawings out) does not create any "evidential gap". We know exactly what happens when $\mathrm{T}$ makes the payment to $\mathrm{X}$ : the trust account is replaced with a right worth $f 10$ and $\mathrm{T}$ acquires a right

\footnotetext{
${ }^{26}$ Birks and Smith have each made this point vociferously, thereby dismissing the 'fiction of persistence' in tracing: P. Birks, 'Property, Unjust Enrichment and Tracing' (2001) 54 Current Legal Problems 231; Smith. ${ }^{27}$ Independent Trustee Services v GP Noble Trustees [44]; Credit Agricole Corp and Investment Bank v Papadimitriou [2].

${ }^{28}$ Agip v Jackson [1990] Ch 265; [1989] 3 WLR 1367.

${ }^{29} \mathrm{R} v$ Preddy [1996] AC 815.

${ }^{30}$ None of this lends support to this function of dummy asset tracing: I turn to the justifications below. It is simply to point out that there is no contradiction between tracing and persisting equitable rights.
} 
worth $f_{20}$, which process we can repeat for any subsequent drawings out. However, the same set of facts is reinterpreted by Equity, which treats the current account as a conglomerate mass of identical claims - a "confusion of funds". 31 or "incorporeal mixture". 32 And understood thus, any dealing with a mixed fund does indeed create an evidential gap:

When money has been paid into an account (or, for that matter, into a bucket, if money were often so kept) and there are subsequent drawings out, it is usually not possible to show by evidence exactly when those particular units of value were withdrawn. ${ }^{33}$

Thus, "either the tracing exercise must be regarded as generally foiled by payment into a bank account or it must be supported by artificial presumptions". ${ }^{34}$

These presumptions, or "impasse-breaking rules", are borrowed from cases that involve physical mixtures. ${ }^{35}$ The starting point is the allocation of a claim that is equal to, and abates rateably in proportion to, the value of the respective contributions; 36 this rule applies "whenever the mixture consists of fungibles, whether these be physical assets like oil, grain or wine or intangibles like money in an account". 37

That starting point is supplanted by another wherever the mixing is the product of a wrongful action on the part of one of the contributors. In these cases, any loss is borne by the wrongdoer in the first instance. ${ }^{38}$ In Re Hallett's Estate, ${ }^{39}$ Lord Jessell MR explained this consequence with the following analogy:

The simplest case put is the mingling of trust moneys in a bag with money of the trustee's own. Suppose he has a hundred sovereigns in a bag, and he adds to them another hundred sovereigns of his own, so that they are commingled in such a way that they cannot be distinguished, and the next day he draws out for his own purposes $f, 100$, is it tolerable for anybody to allege that what he drew out was the first $f_{1} 100$, the trust money, and that he misappropriated it, and left

${ }^{31} \mathrm{~J}$ Ames, 'Folllowing Misappropriated Property into its Product' (1906) 19 Harv L Rev 511, 520.

32 Birks, 'Taking Seriously the Differences Between Tracing and Claiming' 4.

33 Ibid.

${ }^{34}$ P Birks, 'The Necessity of a Unitary Law of Tracing' in R Cranston (ed), Making Commercial Law: Essays in Honour of Roy Goode (OUP 1997) 254.

${ }^{35}$ In Smith's words: [W] hen there is a mixed substitution, one person's value is indistinguishably mixed with another's in the new asset. Tracing in this situation is therefore best conducted by analogy to the established rules for following through physical mixtures of indistinguishable things.

36 'A mixed fund, like a physical mixture, is divisible between the parties who contributed to it rateably in proportion to the value of their respective contributions' Foskett v McKeown 141 (Lord Millett).

37 Ibid 141.

${ }^{38}$ For physical mixtures see Indian Oil Corp Ltd v Greenstone Shipping Co SA (Panama) (The Ypatianna) [1988] QB 345; [1987] 3 WLR 869.

39 Re Hallett's Estate (1880) 13 Ch D 696. 
his own $£_{100}$ in the bag? It is obvious he must have taken away that which he had a right to take away, his own $f_{100.40}$

The result must, he thought, be precisely the same for bank accounts: "His money was there, and he had a right to draw it out, and why should the natural act of simply drawing out the money be attributed to anything except to his ownership of money which was at his bankers". 41

In $\mathrm{Re}$ Oatway, ${ }^{42}$ this rule was developed to allow the beneficiary to attribute her portion of the mixed fund to any purchase that returned a profit for the trustee, thus producing the conclusion that the beneficiary is able to "cherry-pick": she can either say that "her funds" are still sitting in the account, or she can say that "her funds" were used to acquire the new right.

So, the basic rule is one of proportionate allocation, and depletion, of claims; that rule is displaced by one that prejudices the wrongdoer in the event of any further dealings with the mixed fund. ${ }^{43}$ Amongst others, these rules are known as the "rules of tracing". Thus, the rules of tracing are an antidote to the evidential gap created by tracing dummy assets in equity, by which equity treats bank money paid and received as an intangible segregable from the customer's claim against her bank.

\section{DUMMY ASSET TRACING AT COMMON LAW}

It is generally understood that there is a parallel, though perhaps more limited, process of tracing at common law. "Tracing into a substitute is possible", we are told, "provided that there has been a 'clean substitution"', ${ }^{44}$ which is to say: the claimant can trace at law from one right into its substitute so long as there is no mixture of the kind considered immediately above.

Yet, much of the work performed by so-called "common law tracing" should be a puzzle to those who analyse bank transfers through the prism of exchange product tracing. We saw above that exchange product tracing is the process of demonstrating that one right (R2) is the product of another (R), in order to transmit a claim from $\mathrm{R}$ to $\mathrm{R} 2$. We also saw how his works in a typical trusts case: $\mathrm{T}$, who was previously accountable to $\mathrm{B}$ for $\mathrm{R}$ as trustee, is now accountable to $\mathrm{B}$ for $\mathrm{R} 2$. It is much more difficult to see how this works at common law. Take the following Example 4:

Example 4: A steals B's bicycle, selling it for $f_{10}$.

40 Ibid 727.

41 Ibid 727

42 Re Oatway [1903] 2 Ch 356.

43 'where a wrongdoer creates an evidential difficulty, that difficulty will be resolved against his interest, save so far as he can himself discharge the onus of proving the contrary' Birks 255

44 A. Burrows, The Law of Restitution (3rd edn, OUP) 123. 
Common law tracing is thought to provide a mechanism for linking B's title to the bicycle with A's title to the $f_{10}$ : the substitution is "clean" in the requisite sense. ${ }^{45}$ But it is difficult to see how: the right that A acquires and which she exchanges is A's title; B's remains with B. And at the relational stage, a transmission of legal title must, if it is to be effective at all, oust that of $A$. The latter problem is made only more acute by the fact of a bank transfer:

Example 5: A fraudulently diverts $f_{10} 10$ from B's account to A's account. A then transfers $£ 10$ to $\mathrm{C}$ from that account.

The assertion that $\mathrm{B}$ is able, by tracing at common law, to transmit a claim at law to the asset in C's hands is an assertion that B can usurp, unilaterally and without notifying the bank, the position of creditor. ${ }^{46}$

In what follows, I will demonstrate that common law tracing is not, and never has been, a form of exchange product tracing. Those cases which establish a distinct version of tracing at "common law tracing" involve bank money paid and received, and in these cases - as in equity - the courts have interposed a notional asset, which is followed from one person to another through the steps of a bank transfer. I will show that the difference between dummy asset tracing in equity and at law goes to the nature of the asset interposed: in equity, the asset is a right; at law, the asset is a physical thing.

\section{Developing common law tracing}

Though most of our tracing cases involve (for reasons that I discuss in what follows) equitable tracing, the best-known instance of exchange product tracing is not a Chancery case; rather it is a case heard in a common law court three decades prior to procedural fusion. In Taylor v Plumer, ${ }^{47}$ Plumer had given his stockbroker, Walsh, a draft for $£ 22,500$ to buy Exchequer bills. Instead of doing this, Walsh exchanged the draft for Bank of England notes, with which he paid US government stock and Portuguese gold coins. Walsh attempted to abscond to the United States, but was apprehended by Plumer's agent, who took the stock and gold from him. Walsh's assignees in bankruptcy brought an action against Plumer in trover, arguing that Walsh's act of fleeing London was an act of bankruptcy, so that the assignees had, at that point, acquired legal title.

Departing from a long line of cases that had placed the agent's authority to act at the heart of the justification for a proprietary claim to the exchange product of a right held on trust, Lord Ellenborough concluded that:

\footnotetext{
45 Burrows: "Examples of clean substitutions are the exchange of a car for a boat; or a cow for a goat; or $£ 1000$ in cash for a picture".

${ }^{46}$ I consider this below, in the text accompanying fn 70-71.

47 Taylor v Plumer (1815) 3 M \& S 562, 105 ER 721.
} 
If the property in its original state and form was covered with a trust in favour of the principal, no change of that state and form can divest it of such trust... for the product of or substitute for the original thing still follows the nature of the thing itself, as long as it can be ascertained to be such, and the right only ceases when the means of ascertainment fail, which is the case when the subject is turned into money, and mixed and confounded in a general mass of the same description. ${ }^{48}$

It is now well documented that the success of the claim at common law in fact depended wholly upon the conclusion that Walsh held the bills on trust, ${ }^{49}$ and was a simple product of the desire to prevent a clash of jurisprudence between Chancery and the common law courts. ${ }^{50}$ The notion that there is a distinct process of tracing "at common law" stems from the interpretation and incorporation of the final clause of that passage, by which Lord Ellenborough reclothed the words of Willes $\mathrm{J}$ in Scott $v$ Surman. ${ }^{51}$ This has cemented the idea that when a claimant cannot point to a fiduciary relationship at the start of the story, she must trace and claim "at common law", which exercise is thwarted whenever it is confronted by a "mixed fund". 52

I shall return to mixtures below. The object of present attention, to which I turn in what follows, is the notion that there is a common law variant of exchange product tracing, which underpins the potential for a claimant to transmit her claim from one right to its traceable proceeds.

\section{Modern common law tracing}

Despite the equitable foundation for common law tracing, it is now well established that there is a distinct process of tracing at common law. ${ }^{53}$ In what follows, I consider three cases that have been particularly influential in shaping that process. In each, the court held that the claimant could trace at law in order to establish title to money debited from the claimant's account by a third party and paid to the defendant.

In Banque Belge pour l'Etranger v Hambrouck, ${ }^{4}$ an employee had forged his employer's signature, thereby procuring a transfer of some $f^{6000}$ from his employer's account to his own account at Farrow's bank. Hambrouck then drew cheques on this account, giving them to his mistress, Mlle Spanoghe, who credited her account with corresponding sums. The Court of Appeal held that Banque Belge could recover $f^{3} 315$ then standing in Mlle Spanoghe's account as "their property": 55 Taylor v Plumer permitted "money though changed in character to be recovered, if it

48 Ibid 726

49 S Khurshid and P Matthews, 'Tracing Confusion' (1979) 95 LQR 78; Smith.

50 Cutts.

51 Scott v Surman (1742) Willes 400.

52 Agip v Jackson.

53 Trustee of FC Jones v Jones 169 (Millett J).

54 Banque Belge pour l'Etranger v Hambrouck.

55 Ibid 333. 
can be traced", 56 and as she had given no valuable consideration, Mlle Spanoghe could not "set up a title derived from Hambrouck, who had no title against the true owner". ${ }^{57}$ Thus, title either remained with the bank throughout, ${ }^{58}$ or it had revested when the bank expressed a desire to disavow the transaction. ${ }^{59}$

In Lipkin Gorman v Karpnale, ${ }^{60}$ Cass, one of the partners of a firm of solicitors, obtained funds from a client account by withdrawing cash by cheque, and by causing funds to be transferred to building society accounts in his name, from which he withdrew cash. He used that cash to gamble in the defendant casino. Lord Goff considered that the solicitors could "trace their property at common law" in the bank account "into its product, i.e. cash drawn by Cass from their client account at the bank". ${ }^{61}$ The court ordered the casino to pay the firm a sum equivalent to that which it had received from Cass, reduced by any sums that it had released as winnings.

In Trustee of FC Jones $v$ Jones, ${ }^{62} \mathrm{Mr}$ Jones had drawn cheques in his wife's favour on his insolvent firm. She used the funds thereby credited to her account to speculate successfully in potato futures. The trustee in bankruptcy was held to be entitled to "trace his money at Midland Bank into the money in the defendant's account with the commodity brokers", 63 and to claim the proceeds of her investments as its property. Lord Millett called this claim "exclusively proprietary", ${ }^{64}$ concluding that, "as from the date of the act of bankruptcy the money in the bankrupts' joint account at Midland Bank belonged to the trustee". ${ }^{55}$ Again, the court held that the claimant retained title throughout, so that the money asset received by Mrs Jones was never hers; she was "in possession of funds to which she had no title". ${ }^{66}$

In each of these cases, the liability of the defendant depended upon the claimant's ability to show a title to the intermediate money asset in the wrongdoer's hands; in each, the court held that it was possible for the claimant to establish such a title, and that this claim was a claim at common law. This claim has proven exceedingly difficult to explain. ${ }^{67}$ In Lipkin Gorman, Lord Goff was not prepared to depart from a line of cases that established that the cash withdrawn from the client account, and that which was transferred from the account into Cass's building

\footnotetext{
56 Ibid 330.

57 ibid.

58 Ibid 327 (Bankes LJ).

${ }^{59}$ Banque Belge pour l'Etranger v Hambrouck 322 (Atkin LJ).

${ }^{60}$ Lipkin Gorman v Karpnale [1991] 2 AC 548.

${ }^{61}$ Ibid 574.

62 Trustee of FC Jones $v$ Jones.

${ }_{63}$ Trustee of FC Jones v Jones [1997] Ch 159, 170.

64 ibid 168.

$65 \mathrm{ibid} 166$. This nominally produced the absurd result that the trustee in bankruptcy was creditor, and in practice permitted the claimant to recover the original sum and profits, all of which had been paid into court.

${ }^{66}$ Trustee of FC Jones v Jones 167.

${ }^{67}$ In L Smith, 'Simplifying Claims to Traceable Proceeds' (2009) 125 LQR 338 Smith says that "There are as many theories of Lipkin Gorman v Karpnale Ltd as there are writers on the subject".
} 
society account, belonged to Cass. ${ }^{68}$ Nevertheless, he held that the cash was "[the solicitors'] property at common law". ${ }^{69}$ This apparent contradiction is exacerbated by the nature of the asset claimed in both Hambrouck and Trustee of FC Jones. If the claimant, by tracing, acquires an immediate claim at common law to the relevant account, it is difficult to avoid the conclusion that she thereby usurps the position of creditor. ${ }^{70}$ This obviates the rules that prohibit secret assignment, and make it impossible for the debtor to know from whom she can obtain a good receipt. As Birks puts it:

Suppose Mrs Jones had taken her $£, 50,000$ from the brokers and disappeared with it. On such facts some agile footwork would have been necessary in order to explain exactly why the brokers should not be liable to pay the same sum over again, to the trustee, as being the only person who could give them a good receipt. ${ }^{71}$

In the next section, I explain that a great deal of this confusion has been caused by aggregating two different types of case. The first, which reflects the fact pattern of Lipkin Gorman v Karpnale, and which I considered above, is as follows:

Example 1.2: T, trustee, holds title to a $f_{10}$ note on trust for $\mathrm{B}$. T buys with it a bottle of wine, without B's authority. T gives the bottle of wine to $\mathrm{X}$.

I argue (like others) ${ }^{72}$ that Example 1.2 involves the common law recognition of a claim in equity, to the object of a trust.

The second type of case, which reflects the fact pattern of Banque Belge $v$ Hambrouck and (less closely) Trustee of FC Jones v Jones, is as follows:

Example 5: A fraudulently diverts $£ 10$ from B's account to A's account. A then transfers $£ 10$ to $C$ from that account.

I argue (unlike others) ${ }^{73}$ that Example 5 involves the pursuit of a notional asset from B to C, which I have called "dummy asset tracing".

\section{Exchange product tracing at common law}

The prevailing view of the common law tracing cases that I have considered so far is that they are mislabelled: in each, the claimants did not acquire a direct claim to

${ }^{68}$ Lipkin Gorman v Karpnale 573.

69 Ibid 574.

70 Fox.

71 Birks, 'Taking Seriously the Differences Between Tracing and Claiming' 7.

72 See e.g. Smith; McFarlane.

${ }^{73}$ For each of Smith and McFarlane, these cases also fall to be analysed as trusts. 
the cash or against the bank; rather they acquired a claim to the defendant's right or, in other words, a trust. ${ }^{74}$

It is relatively easy to reconcile this analysis with the way in which Lord Goff conceptualised the claim in Lipkin Gorman. Lord Goff noted that, "even if legal title to the money did vest in Cass immediately on receipt, nevertheless he would have held it on trust for his partners, who would accordingly have been entitled to trace it in equity"; $; 5$ yet, he emphasised that "your Lordships are not concerned with an equitable tracing claim in the present case, since no such case is advanced by the solicitors, who have been content to proceed at common law". ${ }^{76}$ We have seen that this is precisely the proposition for which Taylor $v$ Plumer stood at the time of its decision, which is that the common law would recognise a personal claim on facts that would have given rise to a trust in equity.

If we adopt this explanation of Lipkin Gorman, the only difference between that case and Taylor $v$ Plumer is that in the former the trust asset was in the hands of a third party at the time of the claim. Thus, the facts are analogous to our Example 1.2:

Example 1.2: $\mathrm{T}$, trustee, holds title to a $f_{10} 10$ note on trust for $\mathrm{B}$. $\mathrm{T}$ buys with it a bottle of wine, without B's authority. T gives the bottle of wine to $\mathrm{X}$.

No explanation beyond the mere fact of receipt is necessary to account for the firm's claim against the casino: the claim that arose upon Cass's substitution persists through the cash transfer to the casino, grounding a claim to the money in its hands.

Yet, though it is possible to construct a strong case - both as a matter of authority and principle - for an equitable account of Lipkin Gorman, that account depends upon three features that make it an uneasy panacea for all of our common law tracing cases. The first is that there must be grounds for the conclusion that the intermediate party is a trustee of the right acquired. The facts of Trustee of FC Jones can be reconciled with that conclusion (though the court did not treat the claim in this way): Mr Jones, as a partner to the firm from which he misdirected funds, might well have been accountable as a matter of primary right for the cheque that he gave to Mrs Jones. ${ }^{77}$ But it is much more difficult to find similar grounds for the conclusion that Hambrouck was a trustee of the account from which he paid Mrs Jones. ${ }^{78}$

\footnotetext{
74 See e.g. Smith 346; McFarlane.

${ }^{75}$ Lipkin Gorman v Karpnale 572.

76 Ibid 572.

77 See 29(1) Partnership Act 1890 and Don King Productions Inc $v$ Warren Don King Productions Inc v Warren [1998] 2 All ER 608; Barber v Rasco International Ltd [2012] EWHC 269.

78 We might be able to reach the conclusion that Hambrouck was a trustee of the cheque, by reference to the mechanics of rescission, but it is ordinarily thought that rescission revests title; the account was not an asset with which the bank began.
} 
Secondly, the equitable account of Lipkin Gorman requires that the third party receive the object of the trust. If this is possible in Trustee of FC Jones, it is not in Hambrouck: the right received by Mlle Spanoghe - title to the cheque and then the right against her bank - was a new right, different from title to the cheque through which Hambrouck debited Pelabon's account or Hambrouck's right against his bank.

Third, the right claimed must be the trust right. And here, neither case fits the trusts analysis: in Trustee of FC Jones, as in Hambrouck, the right claimed was not the cheque that moved from wrongdoer to third party, but the account into which the funds were paid. If there is a reason for reconceptualising these cases on the basis of equitable principles, and treating the steps of payment as a single property transfer, so as to warrant the analogy between Example 1.2 and Hambrouck and FC Jones, we have not yet found it.

\section{Dummy asset tracing at common law}

Example $\mathbf{5}$ is intended to serve as a proxy for the facts of Hambrouck and FC Jones:

Example 5: A fraudulently diverts $f_{10} 10$ from B's account to A's account. A then transfers $£, 10$ to $\mathrm{C}$ from that account.

I argue here that these cases establish a process of "common law tracing" that exists independently of its counterpart in equity, and that this process is a form of dummy asset tracing, in which the notional asset interposed is a physical cash asset.

In Agip v Jackson, ${ }^{79}$ a payment order had been fraudulently altered to name Baker Oil as beneficiary. That order was executed by the claimant's bank, Banque du Sud, which debited their account with $\$ 518,822.92$, and instructed Baker Oil's bank (Lloyds Bank) to credit Baker Oil's account in London with the same sum, giving instructions to its correspondent bank in New York to reimburse Lloyds Bank. Lloyds Bank acted on those instructions. At the third defendant's behest, it then transferred the sum to the account of the defendants' firm with the bank.

The putative problem with tracing at common law tracing lay in the existence of clearing, which the court treated as a form of "mixed fund". 80 We saw above that equity treats money paid and received as a right that retains its integrity as it moves through the steps of transfer, and which survives admixture. Thus, there was "no difficulty in tracing the plaintiffs' property in equity, which can follow the money as it passed through the accounts of the correspondent banks in New York or, more realistically, follow the chose in action through its transmutation". ${ }^{81}$ Millett J was

\footnotetext{
79 Agip v Jackson.

80 Ibid 289.

81 Ibid 289.
} 
clear, however, that tracing at common law has never benefited from the same flexibility. Echoing the words of Lord Greene in Re Diplock, 82 Millett J said:

The common law has always been able to follow a physical asset from one recipient to another. Its ability to follow an asset in the same hands into a changed form was established in Taylor v. Plumer, 3 M. \& S. 562. In following the plaintiff's money into an asset purchased exclusively with it, no distinction is drawn between a chose in action such as the debt of a bank to its customer and any other asset: In re Diplock [1948] Ch. 466, 519. But it can only follow a physical asset, such as a cheque or its proceeds, from one person to another. It can follow money but not a chose in action. Money can be followed at common law into and out of a bank account and into the hands of a subsequent transferee, provided that it does not cease to be identifiable by being mixed with other money in the bank account derived from some other source. ${ }^{83}$

There are four steps to this analysis, which has been taken as the starting point for many accounts of the distinction between common law and equitable tracing: (i) there are two kinds of tracing - tracing from one asset to another in the same set of hands, and tracing from one person to another; (ii) in the latter capacity, common law tracing always demands a physical object; (iii) the common law will treat money in an account as such a physical asset, but (iv) it will not do so if there is a "mixed fund", which is either an account the value of which is attributable to multiple sources, or some element of clearing. Thus, like equity, the common law is able to turn a bank transfer from one person to another into the transfer of a notional asset; unlike equity, the form of that notional asset is a physical cash asset. This difference lies at heart of the common law's inferior capacity to deal with mixed funds: a process that treats money in a "strictly materialistic way" cannot cope with a confusion of fungible claims. ${ }^{84}$

This makes a great deal more sense of the decisions in Banque Belge $v$ Hambrouck and Trustee of FC Jones v Jones: by treating each bank payment as if it transferred a cash asset to the defendant, the court could at once recognise that the payee was creditor and hold that the transfer vested in the claimant a title that could ground a claim to get it back from the eventual recipient. And it provides an explanation for why Lord Millett saw nothing wrong with the conclusion that the trustee's claim in FC Jones was both a claim at law, and a property claim: the subject matter of that claim was not the bank debt - which could only have been owing to Mrs Jones, and which could not have been "owned" at all - but the notional money asset that it

82 Re Diplock [1951] AC 251 520. "The common law approached [tracing] in a strictly materialistic way. It could only appreciate what might almost be called the "physical" identity of one thing with another. It could treat a person's money as identifiable so long as it had not become mixed with other money". 83 Agip v Jackson 285.

${ }^{84}$ Re Diplock 520. 
represented. Thus, Mrs Jones was "in possession of funds to which she had no title". .85

So, there is a distinct process of "common law tracing", which cannot be subsumed within the hybrid analysis of Taylor $v$ Plumer: a claimant may connect a sum wrongfully debited from her account with another credited to that of the defendant by treating the money paid and received as a physical cash asset independent of the underlying account.

\section{A single set of rules?}

There have been many academic and judicial calls to bring common law tracing in line with the equitable approach. ${ }^{86}$ Birks put this most colourfully:

An exercise of identification either can or cannot be conducted. It would be absurd to suppose that it could be conducted vigorously and resourcefully only on Mondays and Thursday, and it is prima facie no less absurd to assert that it can be so conducted only by a plaintiff who has managed to attract the attention of equity. ${ }^{87}$

Indeed, there is no small inconsistency between the conclusions that: (i) Equity permits a claimant to pursue a notional intangible asset into a mixture, by analogy with common law rules for mixtures of physical things, but (ii) that these rules are inapplicable to common law tracing, by which a claimant pursues a notional physical asset. ${ }^{88}$ For so long as we remain committed to the precepts of dummy asset tracing, there are strong arguments for conducting that process in the same way, regardless of whether the claim is a claim at common law, or an equitable claim that follows from a breach of fiduciary duty.

\section{IV.DUMMY ASSET TRACING AND CLAIMING}

In what follows, I consider the role that dummy asset tracing has played in shaping third party liability for bank money misapplied. I deal first with cases that involve equitable liability in "knowing receipt", and second with third party liability at common law. I show that dummy asset tracing has encouraged the view that it is possible for a claimant to assert a continuing (legal or equitable) title to a money asset received by the defendant. This section is descriptive; I consider the justification for dummy asset tracing in the section that follows.

\section{EQUITABLE PROPERTY AND KNOWING RECEIPT}

85 Trustee of FC Jones v Jones 167.

${ }^{86}$ Millett LJ in FC Jones ibid 169. Foskett v McKeown 113 (Lord Steyn), 129 (Lord Millett). Smith 120-130.

87 Birks 243

${ }^{88}$ Fox [7.28]. 
We saw above that the beneficiaries in ITS $v$ GP Noble trustees were permitted to pursue, and assert a "continuing beneficial interest" in, the funds that Mrs Morris acquired from Mr Morris. So, in the following Example 2, and just as if $\mathrm{T}$ had transferred a physical asset, B can rely upon her original title to set up a claim against $\mathrm{X}$ :

Example 2: T, a trustee, holds an account on trust for B. T transfers $f_{10} 10$ from the trust account to that of a third party, $\mathrm{X}$, without B's authority.

Personal liability for the receipt of a trust right is governed by an extension of this logic: $\mathrm{B}$ retains title to the trust property; if $\mathrm{X}$ knows about T's breach, $\mathrm{X}$ is personally liable for the money that she acquires from $\mathrm{T}$ "as if" she were a trustee of it. ${ }^{89}$ Yet, the precise mechanics of that liability have been the subject of some debate, which can be divided usefully into three schools of thought.

The first view of knowing receipt grounds liability in the property rights of $\mathrm{B}$, rather than in any wrong to which $\mathrm{X}$ might be situated as an accessory. In Arthurv Attorney General of the Turks and Caicos Islands, ${ }^{90}$ the Privy Council accepted that "knowing receipt claims, even though for personal relief, are properly viewed as a vindication of pre-existing property rights and are parasitic on those property rights". ${ }^{91}$ For Davies, too, "liability in knowing receipt is not participatory at all. Simply receiving misapplied property is inherently passive... the source of a receiptbased claim lies in the realm of property". ${ }^{2}$ Elsewhere, it has been described as a form of "adverse possession", ${ }^{93}$ though this seems liable to confuse. ${ }^{94}$ The best understanding of this account is that the primary wrong is an equitable version of the common law tort of conversion (though liability is not strict) in which B sues for X's interference with the trust right. Let us call this the "property interference" account.

The second school of thought is that, by receiving the trust right with knowledge, $\mathrm{X}$ actually becomes a trustee. Let us call this the "true trustee account":

\footnotetext{
89 I borrow this language from Paragon Finance v DB Thakerar [1999] 1 All ER 400 408, though we will see that not everyone ascribes to the similic view of liability. For now, I will deal only with cases in which there is some primary trust; I deal below with cases in which the agent acts without authority. Lord Hoffmann: For this purpose the plaintiff must show, first, a disposal of his assets in breach of fiduciary duty; secondly, the beneficial receipt by the defendant of assets which are traceable as representing the assets of the plaintiff; and thirdly, knowledge on the part of the defendant that the assets he received are traceable to a breach of fiduciary duty.

90 Arthur v Attorney General of the Turks and Caicos Islands [2012] UKPC 30.

91 Ibid [38] (Sir Terence Etherton).

92 P Davies, Accessory Liability (Hart 2015) See also D Sheehan, 'Disentangling Equitable Personal Remedies for Receipt and Assistance' (2008) 16 RLR 41: "knowing receipt, however, is a different type of wrong from dishonest assistance. It appears to be a hybrid, possibly unique in being parasitic, but nonparticipatory in any sense".

93 Williams v Central Bank of Nigeria [2014] UKSC 10; [2014] AC 1189 [13] (Lord Sumption).

94 Possession cannot be adverse to any beneficiary without an immediate right to possession; it cannot be adverse to the possessory claim of a trustee who willingly gives it up.
} 
[W] hen the courts say that a knowing recipient is 'personally liable to account as a constructive trustee', they mean exactly what they say: because of the circumstances in which knowing recipients acquire title to the misapplied property, Equity fixes them with custodial duties which are the same as some of the duties which are voluntarily assumed by express trustees..$^{95}$

Mitchell and Watterson do not anywhere explain why this "fixing" occurs, or seek to identify the wrong from which it arises: theirs is an account of the nature of liability, not of its justification. Yet, they reject the view that knowing recipients owe a form of "participatory" liability, so that the true trustee account can be contrasted usefully with the following "accessory account".

The final way in which the knowing recipient's liability has been framed places less emphasis upon the beneficiary's prior property right: receipt is simply one method by which a person might implicate themselves in another's wrongdoing. In Paragon Finance v DB Thakerar, ${ }^{96}$ Millet LJ put it thus:

Equity has always given relief against fraud by making any person sufficiently implicated in the fraud accountable in equity.... In such a case he is traditionally though I think unfortunately described as a constructive trustee and said to be "liable to account as constructive trustee." Such a person is not in fact a trustee at all, even though he may be liable to account as if he were. ${ }^{97}$

This is the "accessory account": the defendant is liable on account of her participation in a primary wrong, to which she is situated as accessory. ${ }^{98}$

The question of whether $\mathrm{X}$ is a trustee properly so called, or whether her liability depends upon a wrong in which she is implicated, arose for consideration in Williams v Central Bank of Nigeria. ${ }^{99}$ In that case, the claimant had participated in a transaction under which it was alleged that he had been defrauded of some $\$ 6.5$ million, which money had been paid into an account maintained by the defendant in England. The question was whether, having brought his claim 14 years after it accrued, the claimant's action was time-barred. Section 21(3) of the Limitation Act prescribes a six-year period for any "action by a beneficiary to recover trust property or in respect of any breach of trust" not otherwise covered by the Act. However,

\footnotetext{
${ }^{95}$ C Mitchell and S Watterson, 'Remedies for Knowing Receipt' in C Mitchell (ed), Constructive and Resulting Trusts (Hart 2010).

${ }_{96}$ Paragon Finance v DB Thakerar.

${ }^{97}$ Ibid 408, citing Ungoed J in Selangor United Rubber Estates Ltd v Cradock (No.3) [1968] 1 WLR 15551582.

${ }_{98}$ For the argument that both knowing receipt and dishonest assistance belong to the same participatory wrong, see Lord Nicholls, 'Knowing Receipt: The Need for a New Landmark' in W. Cornish and others (ed), Restitution: Past, Present and Future: Essays in Honour of Gareth Jones (Hart); P. Birks, 'Receipt' in P. Birks and A. Pretto (eds), Breach of Trust (Hart), and Consul Development Pty Ltd v DPC Estates Pty Ltd [1975] 132 CLR 373; Fyffes Group Ltd v Templeman [2000] 2 Lloyds Rep 643.

${ }_{99}$ Williams v Central Bank of Nigeria.
} 
section 21(1)(a) of the 1980 Act provides that: "No period of limitation prescribed by this Act shall apply to an action by a beneficiary under a trust, being an action in respect of any fraud or fraudulent breach of trust to which the trustee was a party or privy". Thus, one of the arguments advanced for the claimant was that a knowing recipient could be regarded as a "trustee" for the purposes of section 21(1)(a).

A majority of the Supreme Court held that it could not. According to Lord Sumption, the reason why the clock does not run in an action against a trustee in respect of the misapplication of trust assets is that a trustee's liability does not depend upon proof of any breach. Rather, "if the trustee misapplied the assets, equity would ignore the misapplication and simply hold him to account for the assets as if he had acted in accordance with his trust". ${ }^{100}$ By contrast, strangers to the trust who receive trust assets misappropriated in breach of duty are liable "by virtue of their participation in the unlawful misapplication of trust assets". ${ }^{101}$

Though it was not necessary to decide the point to dispose of the appeal, Lord Sumption appears to have understood knowing receipt as a form of liability that is parasitic upon the breach of trust, rather than (like Sir Terence Etherton in Artburv Attorney General of the Turks and Caicos Islands) the beneficiary's property rights. $\mathrm{He}$ emphasised that knowing receipt involves a dealing with trust assets that is "adverse to the beneficiaries"; 102 yet, he described both dishonest assistance and knowing receipt as two forms of "ancillary liability":

Either they have dishonestly assisted in a misapplication of the funds by the trustee, or they have received trust assets knowing that the transfer to them was a breach of trust. In either case, they may be required by equity to account as if they were trustees or fiduciaries, although they are not. These can conveniently be called cases of ancillary liability. The intervention of equity in such cases does not reflect any pre-existing obligation but comes about solely because of the misapplication of the assets. ${ }^{103}$

So, there are three accounts of liability in knowing receipt: for property interference and true trustee accounts, dummy asset tracing goes to show that $\mathrm{X}$ received a right to which B has a superior claim; for the accessory account (for which there is now increased support), dummy asset tracing goes to show that $\mathrm{X}$ was implicated in the fraud by which B was stripped of the trust asset.

\footnotetext{
100 Ibid [13].

${ }^{101}$ Ibid [13].

102 Ibid [13].

103 Indeed, he used the labels "dishonest" and "knowing" interchangeably for each type of liability.
} 


\section{LEGAL PROPERTY AND UNJUST ENRICHMENT}

According to Burrows, the decision in Hambrouck exemplifies a "title and tracing" exception to the ordinary rule that the claimant who seeks to recover money from the defendant in an action for restitution of an unjust enrichment must be the "direct provider" of that sum:104 "by means of tracing and title, a claimant can show that value in a substitute asset comprises a transfer of value from the claimant: one is tracing value as it is transferred from the claimant's asset to its substitute". ${ }^{105}$ Thus, in the following Example 5, B can trace through each substitution (B's right for A's right, A's right for C's right), thereby demonstrating that the credit to C's account represents a transfer of value from her:

Example 5: A fraudulently diverts $£ 10$ from B's account to A's account. A then transfers $£ 10$ to $\mathrm{C}$ from that account.

Framed as a process of pursuing value, Taylor v Plumer and Hambrouck appear identical: the claimant can either pursue value from one right to another through an exchange, or she can pursue value from one person to another through a transfer; either way, the claimant can show that the defendant received value that emanated from her. I have argued elsewhere that this is a mistake, which conflates two distinct kinds of value. ${ }^{106}$ The first is the susceptibility of a right to exchange (which I have called exchange potential); this is the kind of value involved in exchange product tracing, and it does not move from one right to another. The second is wealth (value measured as a sum of the purchasing power to which an individual has recourse, minus her liabilities). This is the kind of value involved in a bank transfer from one person to another, and it provides no mechanism for connecting B's account with that of $C$, with whom B had no dealings, so as to substantiate B's claim that $C$ should reverse A's wrongful debit.

Birks offers a different, simpler, account of three-party cases. For Birks, "a receipt of your money is always a receipt directly from you", ${ }^{107}$ so that if the claimant can establish a proprietary claim to the thing or right transferred to the defendant, it is irrelevant that she did not effect the transfer herself:

If I find your wallet it makes no difference whether I am the first recipient or the second or the twenty-second. Suppose a pickpocket took it and, in alarm, threw it down, and then I found it. My position would be exactly the same as if your wallet had fallen from your pocket into the road in front of me without your noticing its loss..$^{108}$

\footnotetext{
104 Burrows 119.

105 Ibid 119 .

${ }^{106}$ Cutts (forthcoming, OJLS).

107 Peter Birks, Unjust Enrichment (OUP 2004) 87.

108 Peter Birks, Unjust Enrichment (OUP 2004) 87.
} 
Thus, the "proprietary connection" that justifies the claimant's claim against a party with whom she did not transact directly is not an exception to the direct provider rule; it is an application of it.

Birks applies this account directly to the facts of Hambrouck, 109 thereby treating the money paid by the bank to Hambrouck, and by Hambrouck to Mlle Spanoghe, as transfer akin to that of a physical cash asset. We have already seen that this is precisely the approach adopted by the court in that case, which encouraged the conclusion that Mlle Spanoghe could not "set up a title derived from Hambrouck, who had no title against the true owner". ${ }^{110}$ This is what I have called dummy asset tracing, and it allows us to conceptualise Example $\mathbf{5}$ as a simple transfer of money that is owned by the claimant at law into the hands of a third party: $\mathrm{C}$ receives a notional cash asset to which $\mathrm{B}$ has a better title.

There has been some debate about whether cases that involve receipt of the claimant's property are appropriately termed "unjust enrichment" at all. ${ }^{111} \mathrm{I}$ have considered this elsewhere, ${ }^{112}$ and will not dwell on it here, save to say this: to the extent that the legal event responsible for the creation of liability is some breach of a (real or putative) exclusionary obligation, the alternative clothing in unjust enrichment seems at best unnecessary, and at worst confusing.

However, we have not yet addressed the question that is logically prior to the appropriate categorisation of common law claims against third parties for bank money misappropriated: I will consider in the penultimate part of this paper whether these cases should be governed by the notion of a property transfer at all.

\section{V.CRITIQUING DUMMY ASSET TRACING}

Birks described dummy asset tracing as a "metaphorical" process. ${ }^{113}$ Yet, we have seen that it is not merely a figure of expression: dummy asset tracing is a legal device, the use of which has manifest consequences for third parties. It allows us to forge a connection between a claimant from whose account money was wrongfully debited, to an innocent third party whose account was credited by the wrongdoer, by virtue of the latter's receipt and possession of a monetary asset that previously belonged (at law or in equity) to the claimant. As such, we should make sure that it can be defended robustly.

Whenever it has been necessary to formulate an explanation for dummy asset tracing, ${ }^{114}$ it is usually along the following lines: there would be liability if the facts

\footnotetext{
109 P. Birks, Unjust Enrichment (OUP) 86-87.

$110 \mathrm{ibid}$. Trustee of FC Jones, too, we saw that this guided Millett LJ's conclusion that Mrs Jones 'in possession of funds to which she had no title' Trustee of FC Jones $v$ Jones 167.

111 See e.g. W. Swadling, 'Ignorance and Enrichment: the Problem of Title' (2008) 28 OJLS 627.

112 Cutts, 'Modern Money Had And Received" Forthcoming, OJLS.

113 Birks, 'Taking Seriously the Differences Between Tracing and Claiming' 4.

114 And I suspect that a substantial part of what instigated dummy asset tracing is a an impulse towards framing things by reference to familiar ideas.
} 
involved dealings in physical money; thus, liability cannot be escaped by the mere fact that the money happens to take an intangible form. ${ }^{115}$ This can be framed institutionally, or at an individual level.

Proctor, present editor of Mann on the Legal Aspect of Money, presents the institutional argument instrumentally: "if money is to exist in several different forms, then the law should certainly ensure that the rights of a person who receives 'money' are the same, irrespective of the precise form in which that money is conveyed". 116 Thus, the law must attribute to bank media "characteristics which will enable it effectively to fulfil functions which similar to those performed by notes and coins". 117 One such characteristic goes to the circumstances in which money can be recovered from payees: though money can, by tracing, be "followed in rem against a holder who acted in bad faith or gave no consideration", it must be generally irrecoverable from a good faith payee. ${ }^{118}$

This requires some unpacking. By way of contrast with the treatment of other tangible assets, cash cannot be recovered from a good faith payee. ${ }^{119}$ This helps to ensure the free currency of money by affording confidence to the holder that they will not be deprived of it. ${ }^{120}$ Yet, for bank payments, that confidence is already supplied by the irrevocability of the payment instruction by which credit is transferred. ${ }^{121}$ It is only by treating bank money as property that we first encounter the need to limit the circumstances in which it can be recovered; the instrumental argument fails to justify treating bank money as property.

The analogical argument is weaker at the individual level. We have already seen that the effect of dummy asset tracing at law is that an individual can be made accountable for their putative receipt of a notional asset to which the claimant has or had a better claim. Liability is strict, and it replicates the conditions for and consequences of property. This ought to be somewhat surprising. That we should be chary of extending the ambit of exclusionary duties was the thrust of the decision in $O B G \vee$ Allan, ${ }^{122}$ that a person who sought to usurp the contractual claim of another could not be held liable in conversion. There being no tangible asset, there was nothing to form the object of a claim that the defendant owed and had breached an obligation to stay away. There are good reasons for this: it is usually far easier for someone to recognise and comply with exclusionary obligations in respect of tangible objects.

Yet, there is a strong sense in which the contract in $O B G v$ Allan was a better candidate for ownership than bank money paid: if the exclusionary responsibility

\footnotetext{
115 Re Hallett's Estate.

116 C. Proctor, Mann on the Legal Aspect of Money (7th edn, OUP) 43.

117 ibid.

118 ibid.

119 Miller v Race (1758) 1 Burr 452, 97 ER 398.

120 Ibid 459: speaking of banknotes, Lord Mansfield considered it "necessary, for the purposes of commerce, that their currency should be established and secured"; thus the defence would be available to the recipient of notes, as to the recipient of coins.

121 The Brimnes [1973] 1 WLR 386; Tayeb v HSBC Bank [2004] EWCH 1529, [2004] 4 All ER 1024.

122 OBG Ltd v Allan [2007] UKHL 21; [2008] 1 AC 1.
} 
were to extend only to a true usurpation of contractual rights, it would not often be possible to breach it accidentally. By contrast, dummy asset tracing precipitates a liability for interfering with the (fictional) property claim of a person who may be wholly unknown to the defendant, on the basis of a defective transaction that occurred at some point in time prior to the immediate payment. It is extremely easy to interfere with such a claim accidentally; indeed, such was the court's conclusion as to Mrs Jones' position in Trustee of FC Jones v Jones.

In what follows, I present the case for limiting the circumstances in which a third party can be held liable to someone with whom she did not transact.

\section{VI.REPLACING DUMMY ASSET TRACING}

We are not bound to dummy asset tracing. We have already seen that there is support, in and out of the courts, for an approach that locates liability, not in the defendant's putative receipt of some asset belonging (at law or in equity) to the claimant, but in her proximity to the relevant injustice. ${ }^{123}$ In what follows, I make the case for extending that approach to all cases that currently fall within the territory of dummy asset tracing.

\section{KNOWING RECEIPT: INTERFERING WITH THE TRUST, AND} DEFECTIVE TRANSACTIONS

Let us return to Example 2:

Example 2: T, a trustee, holds an account on trust for B. T transfers $£ 10$ from the trust account to that of a third party, X, without B's authority.

Without dummy asset tracing, the claimant cannot pin the defendant's liability on the notional receipt of an asset to which the claimant has a continuing claim; we must find some other foundation for liability in so-called "knowing receipt". In fact (though the label seems inapt), we retain material for both sides of the debate concerning whether liability in knowing receipt is a primary or participatory wrong: either knowing receipt is a type of accessory liability, in which the primary wrong takes the particular form of misapplying trust rights; alternatively, knowing receipt is a type of primary wrong, akin to conversion at law, but which involves an interference with trust rights other than through receiving them. Either way, $\mathrm{X}$ is

123 Williams v Central Bank of Nigeria. 
liable because she is situated as a party to a transaction that has the immediate effect of disabling $\mathrm{T}$ from performing the trust. ${ }^{124}$

A more substantial consequence of the departure from dummy asset tracing concerns the manner in which we conceptualise cases that do not involve a breach of fiduciary duty by a non-trustee. Take the following example:

Example 6: A, director of B Co, pays money from B Co to C without B Co's authority.

The language of tracing has made it possible to avoid detailing the specific nature of the wrong in several such cases. Importantly, few of these cases involve any primary trust, so that the terminology and logic of "trust property" misdirected is inappropriate.

In BCCI v Akindele, ${ }^{125}$ the defendant, Akindele, entered into an agreement with ICIC Ltd, a company controlled by the BCCI group, to pay $\$ 10$ million for shares in another company in the same group. Under the agreement, the defendant was guaranteed a return of 15 per cent if he decided to sell his shares after two years, which he did. Payment was made by BCCI Overseas, which was subsequently reimbursed by ICIC Ltd. The reason for the arrangement was to boost BCCI's apparent capital. The liquidator sought to hold the defendant liable for knowing receipt, arguing that the defendant acquired the funds with "constructive knowledge of a misapplication of trust property". ${ }^{126}$ Nourse LJ accepted the argument from tracing, though he rejected the claim for lack of knowledge.

Relfo $v$ Varsani concerned a claim brought by the liquidator of Relfo Ltd ("Relfo") against Mr Varsani to recover $\$ 878,479.35$ that had been misappropriated by its former director, Mr Gorecia. ${ }^{127} \mathrm{Mr}$ Gorecia, in breach of fiduciary duty, caused Relfo to pay $\$ 890,050$ to a company called Mirren Ltd ("Mirren"). The next day, another company, Intertrade Group LLC ("Intertrade"), paid $\$ 878,479.35$ to Mr Varsani's bank account. Explaining that "Tracing enables a beneficiary to recover trust property that has been misappropriated", 128 Arden LJ held that Varsani was liable in knowing receipt.

Conaglen and Nolan argue that the failure to elucidate the distinction between trustees and custodial fiduciaries who are not trustees, but who occupy the position of agent, is one of the primary obstacles to understanding liability in knowing receipt. They point out that, "despite the superficial similarity between trustees, who act "on behalf of the trust", and true agents, such as company directors, these two

\footnotetext{
124 There may be one practical difference entailed by the conclusion that the defendant's liability is not based on her receipt of a right to which the beneficiary has a better claim: the subsequent acquisition of knowledge ought not to convert the receipt of money into a primary or participatory wrong for interference with the trust Baden v Societe Generale pour Favoriser le Developpement du Commerce et de l'Industrie en France $S A$ [1993] 1 WLR 509, [1992] 4 All ER 161, 403.

125 Bank of Credit and Commerce International (Overseas) Ltd v Akindele [2001] Ch 437; [2000] 3 WLR 1423.

126 Ibid 440.

127 Relfo $v$ Varsani.

128 Ibid [65].
} 
categories of legal actors enter into contracts in fundamentally different capacities". ${ }^{129}$ Without dummy asset tracing, we are able to address this distinction directly. Rather than basing liability on a loose analogy with cases that involve a misdirection of trust property, C's liability can be explained on its own terms. And on its own terms, Example 6 fits the model of a standard two-party restitutionary claim: B Co, who is made a party to the transaction effected by its agent, A, can set the contract aside and recover money paid to $\mathrm{C}$ as an unjust enrichment at its expense.

If we adopt this approach, a great deal turns on whether or not the transaction was authorised, which question was altogether ignored in BCCI $v$ Akindele. If the directors were authorised to execute the transaction, there should have been no question of the company seeking to claim back the funds paid; if they were not, the company could have set aside the contract and sought restitution.

\section{STRICT LIABILITY AT COMMON LAW}

It remains to address Example 5, in which strict liability has been founded upon the receipt of a notional asset owned by the claimant at law:

Example 5: A fraudulently diverts $£ 10$ from B's account to A's account. A then transfers $£, 10$ to $\mathrm{C}$ from that account.

These cases are the most important casualty of the decision to replace dummy asset tracing: $\mathrm{C}$, who neither participates in the fraud through which $\mathrm{B}$ 's funds were misdirected, nor transacts directly with B, ought not to be made accountable for B's loss; B's proper defendant is A. ${ }^{130}$

Not all of our decisions on so-called "common law tracing" will be undermined by this conclusion. If we can find an explanation for the firm's proprietary claim to the cash held by Cass in Lipkin Gorman, we might be able to explain the casino's liability for the cash that it received from Cass. That liability, if it can be justified, must be in the nature of a trust, and the casino's liability for the receipt of trust property. But two decisions that have been considered crucial to the development of principles of common law tracing are undermined by the departure from dummy asset tracing: in Trustee of FC Jones v Jones and Banque Belge pour l'Etranger v Hambrouck, neither defendant should have been liable (for the original sum received or for profits made by investing it) to a claimant with whom they did not transact, and against whom they committed no primary or participatory wrong.

\footnotetext{
${ }^{129}$ M Conaglen and R Nolan, 'Contracts and knowing receipt: principles and application” LQR 359.

${ }^{130} \mathrm{I}$ have assumed support for the requirement of directness in unjust enrichment. For contrary views see e.g. S. Watterson, “"Direct Transfers" in the Law of Unjust Enrichment' (2011) 64 CLP 435.
} 


\section{COMMON LAW TRACING}

It should be clear that a by-product of the analysis in this article is that there is no role for "common law tracing" within or without the context of bank transfers. I have presented the case for eliminating dummy asset tracing, and have suggested that exchange product tracing ought only to deliver a proprietary claim in the nature of a trust.

However, we must be careful not to make too much of this conclusion. There have been many arguments to the effect that a corollary of the loss of a distinct law of tracing at common law is the loss of any distinct role for fiduciary duties in establishing a connection between old and new assets. ${ }^{131}$ Yet, quite apart from reducing the importance of fiduciary duties, replacing dummy asset tracing may place a renewed emphasis on the status of the party responsible for the loss. There may well be an argument from fiduciary responsibility for allowing a beneficiary to "cherry-pick" the product of an unauthorised investment made by the trustee, which does not also require us to treat the account as a corporeal confusion of funds; such an argument would necessitate careful consideration of the scope and form of the core custodial duty.

This is what we gain by replacing dummy asset tracing, and it warrants emphasis: arguments that concern the existence and extent of liability cannot be made by simple analogy with cash transfers; rather, they must be made with clear reference to the role of the defendant in instigating the loss for which the claimant sues, and the contours of the relationship between them.

\section{VII.CONCLUSION}

I have argued that tracing money through bank transfers is a process distinct from tracing through substitutions, which we have called "exchange product tracing". A claimant who traces through bank payments and claims in equity does so on the basis of a notional rights-transfer; a claimant who traces through bank payments and claims at law does so on the basis of a notional transfer of some physical thing. I have called these processes "dummy asset tracing".

I have demonstrated that dummy asset tracing has important third party consequences: it permits a claimant to connect her account (from which funds were wrongfully debited) with the account of an innocent third party (into which funds have been credited), for the purposes of establishing a claim to the latter. I have argued that we should articulate the defendant's role in that misallocation of funds more clearly, and that so doing presents a narrower account of liability: the defendant is liable either because she actuated or participated in a breach of some

131 See e.g. Smith. 
duty owed to the claimant, or because the claimant's agent lacked the authority to effect the bank transfer to her. 